\title{
Role of nitrate in nitrogen nutrition of the mangrove Avicennia marina
}

\author{
K. Boto ${ }^{1}$, P. Saffigna ${ }^{2}$ and B. Clough ${ }^{1}$ \\ ${ }^{1}$ Australian Institute of Marine Science, P.M.B. No. 3, Townsville M.C., Queensland 4810, Australia \\ ${ }^{2}$ School of Australian Environmental Studies, Griffith University, Nathan, Queensland 4111, Australia
}

\begin{abstract}
A crucial role of nitrate uptake in the nitrogen nutrition of the mangrove Avicennia marina (Forsk.) Vierh. has been indicated from 2 laboratory pot culture experiments: (1) Seedlings grown for $63 \mathrm{~d}$ in ${ }^{15} \mathrm{NH}_{4}^{+}$-enriched anaerobic soil exhibited markedly reduced (by $50 \%$ ) nitrogen uptake when a nitrification inhibitor ( $\mathrm{N}$-serve) was added to the soil, compared to controls where no $\mathrm{N}$ serve was added. (2) Seedlings grown for $158 \mathrm{~d}$ in aerobic solution culture showed poor growth, complete lack of fine root development and low nitrogen uptake when supplied with ammonium as the sole nitrogen source. Increased ammonium supply, at 5, 10, 30 and $50 \mathrm{ppm}$ (N) levels, did not significantly enhance growth in any of the plant components (leaves, stems, roots). Conversely, seedlings supplied with nitrate (only) showed extensive fine root development and good aboveground growth which was significantly enhanced by increased nitrate supply up to $30 \mathrm{ppm}(\mathrm{N})$.
\end{abstract}

\section{INTRODUCTION}

There is considerable interest in the nitrogen nutrition of plants growing in waterlogged saline soils, most notably evidenced by the abundant literature on Spartina salt marshes in the U.S. Several studies, carried out over a wide range of localities, have demonstrated that nitrogen fertilization increases the productivity of Spartina alterniflora marshes, implying that nitrogen limitation of these systems is widespread (e.g. Valiela and Teal, 1974; Gallagher, 1975; Buresh et al., 1980). Other studies (Mendelssohn, 1979; Teal et al., 1979), however, have suggested that this positive response is paradoxical since marsh sediments commonly contain high concentrations of dissolved inorganic nitrogen, mainly in the ammonium form. This view was supported by Morris (1980) who determined half-saturation constants for inorganic nitrogen uptake which indicate that, in aerobic conditions, natural sediment ammonium levels should be sufficient to sustain maximum growth.

It has been proposed, therefore, that the apparent nitrogen limitation may be related to the anaerobic nature of most marsh soils (Mendelssohn, 1979; Howes et al., 1981; Morris, 1980). Similar, although much

Contribution No. 249 from the Australian Institute of Marine Science more limited, observations have been made for mangrove systems. For example, mangrove forests in Florida have been shown to respond positively to natural enrichment by guano (Onuf et al., 1977), while Boto and Wellington (1983) have reported a significant growth response following ammonium fertilization of a mangrove forest in northern Australia. The latter investigators have also found, however, that above ground biomass was correlated with the soil redox potential (Eh) and that new leaf nitrogen content was also significantly correlated with Eh (Boto and Wellington, 1983, 1984).

It is generally accepted that plants such as rice (Armstrong, 1971), Spartina (Teal and Kanwisher, 1966, Gleason and Zieman, 1981) and mangroves (Scholander and Scholander, 1955) translocate oxygen to their roots to satisfy metabolic requirements, and that subsequent oxygen diffusion into the soil creates a thin aerobic layer around the roots. This oxidized zone may assist in prevention of sulphide (Armstrong, 1978) or iron toxicity (Mendelssohn and Postek, 1982) through oxidation to sulphate and less soluble iron (III) states respectively. It is also possible that these zones support populations of nitrifying bacteria, providing nitrate for plant uptake. Mendelssohn (1979) measured low levels of root and leaf nitrate reductase activity and nitrate in S. alterniflora. and concluded that nitrate was not an important nitrogen source for these plants. 
The results did, however, show that nitrate uptake was significantly greater in the more vigorous streamside plants. This suggested to us that the role of nitrate in the nitrogen nutrition of plants growing in anaerobic soils deserved further attention.

\section{MATERIALS AND METHODS}

Plant material. Seedlings of Avicennia marina were used in both experiments. This species was considered eminently suitable for this study owing to its widespread occurrence in Australian mangrove systems, its ease of propagation and its tolerance of highly anaerobic, perpetually flooded, soils (Saenger, 1982). The seedlings were initially allowed to develop from the propagule stage by placement in wet sand. Following development of at least 4 leaves and a healthy root system, seedlings of similar initial fresh weights were chosen for the nutrition experiments. All experiments were carried out in a shadehouse where incident light was reduced to about one-third of full sunlight.

Anaerobic soil experiment (Experiment 1). The soil for this experiment was obtained from an intertidal mangrove zone and has been described previously (Boto and Wellington, 1984). Briefly, the soil is a fine silt containing about $20 \%$ organic matter, $0.3 \%$ total nitrogen and $0.03 \%$ total phosphorus on a soil dry weight basis. Previous field experiments (Boto and Wellington, 1983) have shown that the mangroves at this site responded positively to soil ammonium enrichment but not to superphosphate addition. The soil was stored wet and thoroughly blended before use. Four samples taken at the start of the plant uptake experiment (before ${ }^{15} \mathrm{~N}$ additions) showed that the mean extractable $\mathrm{NH}_{4}^{+}-\mathrm{N}$ level was $19.2 \mu \mathrm{g} \mathrm{N} \mathrm{g}^{-1}$ (dry soil) and was acceptably uniformly distributed (s.d = 1.3). The mean soil nitrate concentration was 1.0 ( $\pm \mathrm{s.d}$ $=0.5) \mu g \mathrm{Ng}^{-1}$ dry soil.

The soil was placed into 20 PVC pots (12 with seedlings), each pot having external dimensions of $8 \mathrm{~cm}$ diameter $\times 14 \mathrm{~cm}$ length. Approximately $400 \mathrm{ml}$ of soil slurry ( $75 \%$ water content) was added to each pot, sufficient to cover the roots of each plant. After allowing the soil to dry sufficiently to absorb treatment solutions, a total of $10 \mathrm{ml}$ of ${ }^{15} \mathrm{~N}$-enriched $\left(\mathrm{NH}_{4}\right)_{2} \mathrm{SO}_{4}$ (77.6 atom $\%$ $\left.{ }^{15} \mathrm{~N}\right)$ solution containing $2.50 \mathrm{mg}$ of $\mathrm{NH}_{4}^{+}-\mathrm{N}$ was injected into the soil in each pot, at several different positions to ensure uniformity and to prevent leakage to the soil surface. A nitrification inhibitor, N-serve (2-Chloro-6trichloromethyl pyridine-Dow Chemical Co.) was also added to 10 of the pots ( 6 with plants), the amount added corresponding to a final concentration of $5 \mathrm{ppm}$ in the soil water (Billen, 1976). Similar quantities of $\mathrm{N}$-serve were added at 14 to $18 \mathrm{~d}$ intervals to maintain efficient nitrification inhibition (Sahrawat and Mukerjee, 1977). After all injections, the soil surface was tamped down and distilled water was added at frequent intervals to maintain a level of 3 to $5 \mathrm{~mm}$ above the soil surface. Redox probes placed in 4 of the pots ( 1 in each treatment type, i.e. plant + soil, soil only and with/without $\mathrm{N}$ serve) showed that anaerobic conditions were quickly achieved; $2 \mathrm{~h}$ after treatment additions, the Eh was in the range -140 to $-160 \mathrm{mV}$ in each pot and remained constant to within $\pm 10 \mathrm{mV}$ throughout the experiment.

The experiment was terminated $63 \mathrm{~d}$ after ${ }^{15} \mathrm{~N}$ additions. Aboveground plant portions were removed and dried to constant weight at $60^{\circ} \mathrm{C}$. The soil was washed away from the roots which were added to the corresponding upper plant portions. Following the addition of $300 \mathrm{ml}$ of $4 \mathrm{M} \mathrm{KCl}$, the soils were shaken for $1 \mathrm{~h}$ and the extract solution cleared by filtration. The dried, ground soil residue was analysed for total $\mathrm{N}$ and ${ }^{15} \mathrm{~N}$, extract solutions analysed for $\mathrm{NH}_{4}^{+},\left(\mathrm{NO}_{3}^{-}+\mathrm{NO}_{2}^{-}\right)$and ${ }^{15} \mathrm{~N}$, and the dried, ground plant samples analysed for total $\mathrm{N}$ and ${ }^{15} \mathrm{~N}$. The Kjeldahl digestion and steam distillation methods used for these analyses have been described by Bremmer (1965), Bremmer and Keeney (1966), and Saffigna and Waring (1977). A Micromass 622 isotope-ratio mass spectrometer was used to determine the ${ }^{15} \mathrm{~N}$ enrichment of the nitrogen gas produced by reaction of the dried $\mathrm{NH}_{4}^{+}$salts with lithium hypobromite as described by Ross and Martin (1970). The recovery of added ${ }^{15} \mathrm{~N}$ in the soil, extract solution and plants was determined from the product of the $\mathrm{N}$ content and the ${ }^{15} \mathrm{~N}$ enrichment after correcting for background.

Aerobic hydroponic culture (Experiment 2). Seedlings were grown in continuously aerated solutions containing $25 \%$ seawater and all essential primary and trace nutrients except nitrogen (Table 1). Nitrogen was supplied to the plants as ammonium sulphate or

Table 1. Composition of culture solutions for Experiment 2. All solutions were $25 \%$ seawater and contained 5 ppm Nserve. The concentrations of added essential nutrient elements, except nitrogen, are tabulated below

\begin{tabular}{|c|c|c|}
\hline Element & $\begin{array}{c}\text { Added } \\
\text { as }\end{array}$ & $\begin{array}{c}\text { Conc. of } \\
\text { element (ppm) } \\
\text { in culture solution }\end{array}$ \\
\hline $\mathrm{P}$ & $\mathrm{NaH}_{2} \mathrm{PO}_{4}$ & 10 \\
\hline$K$ & $\mathrm{KCL}$ & 290 \\
\hline $\mathrm{Mg}$ & $\mathrm{MgSO}_{4}$ & 1000 \\
\hline $\mathrm{Fe}(\mathrm{II})$ & EDTA complex & 5 \\
\hline B & Borax & 0.2 \\
\hline $\mathrm{Mn}(\mathrm{II})$ & $\mathrm{MnSO}_{4}$ & 0.2 \\
\hline $\mathrm{Zn}$ & $\mathrm{ZnSO}_{4}$ & 0.1 \\
\hline $\mathrm{Cu}$ & $\mathrm{CuSO}_{4}$ & 0.02 \\
\hline Mo & $\mathrm{NaMoO}_{4}$ & 0.0004 \\
\hline $\mathrm{Co}$ & $\mathrm{CoSO}_{4}$ & 0.0004 \\
\hline
\end{tabular}


Table 2. Mean ${ }^{15} \mathrm{~N} \%$ recovery in soils and plants from Experiment 1

\begin{tabular}{|c|c|c|c|c|}
\hline & $\begin{array}{c}\text { Soil } \\
\text { immobilized }{ }^{15} \mathrm{~N}\end{array}$ & $\begin{array}{c}\text { Soil } \\
\text { mineral }{ }^{15} \mathrm{~N}\end{array}$ & $\begin{array}{l}\text { Plant } \\
{ }^{15} \mathrm{~N}\end{array}$ & ${ }^{\text {Total }}$ \\
\hline \multicolumn{5}{|l|}{ Planted pots } \\
\hline No $N$-serve $(n=6)$ & 34 & 1 & 54 & 88 \\
\hline N-serve $(n=6)$ & 62 & .8 & 26 & 89 \\
\hline $\mathrm{LSD}_{.05}$ & 8 & .2 & 10 & 8 \\
\hline \multicolumn{5}{|l|}{ Soil-only pots } \\
\hline No $N$-serve $(n=4)$ & $58(73)^{\circ}$ & $12(16)^{\circ}$ & - & $70(89)^{*}$ \\
\hline$N$-serve $(n=4)$ & 75 & 9 & - & 84 \\
\hline $\operatorname{LSD}_{.05}$ & $26(16)$ & $8(7)$ & - & $30(16)$ \\
\hline
\end{tabular}

potassium nitrate, each at 4 different levels: $5,10,30$ and $50 \mathrm{ppm} \mathrm{N}$. Each treatment group contained 5 replicate seedlings giving a total of 40 seedlings. The nitrification inhibitor, $\mathrm{N}$-serve, was added to all solutions at the $5 \mathrm{ppm}$ level. Solutions were changed every $2 \mathrm{wk}$ and between changes were monitored for $\mathrm{NH}_{4}^{+}$and $\mathrm{NO}_{3}^{-}\left(+\mathrm{NO}_{2}^{-}\right)$content at 2 to $3 \mathrm{~d}$ intervals. Despite constant aeration, nitrate losses were relatively severe, equivalent to about $5 \mathrm{ppm}$ every 2 to $3 \mathrm{~d}$. Ammonium loss was less severe, although occasional additions to those solutions were also required to maintain the nominal treatment levels. The $\mathrm{NO}_{3}\left(+\mathrm{NO}_{2}\right)$ levels in all ammonium solutions was consistently less than $0.1 \mathrm{ppm} \mathrm{N}$. After $158 \mathrm{~d}$ of treatment, the plants were harvested for fresh and dry weight determinations of leaves, stems and roots. Total leaf area per plant was measured using a Licor leaf area meter. The dried plant components were finely ground in an agate mill and analysed for total $\mathrm{N}$ using a LECO CHN analyser.

Data analysis. The data from Experiments 1 and 2 were analysed by standard analysis of variance methods (e.g. Sokal and Rohlf, 1981) and means compared using least significant differences at the $\mathrm{p}<0.05$ level of significance (LSD ${ }_{.05}$ ).

\section{RESULTS}

\section{Experiment 1}

The mean ${ }^{15} \mathrm{~N}$ recoveries, at the end of the $63 \mathrm{~d}$ treatment period, as soil immobilized $N$, soil inorganic $\mathrm{N}$ and plant $\mathrm{N}$ are shown in Table 2. The major features were:

(1) Plant ${ }^{15} \mathrm{~N}$ uptake for the $\mathrm{N}$-serve treatment group was $50 \%$ less $(p<.001)$ than for the group where no $\mathrm{N}$-serve was added.
(2) Conversely, soil immobilized ${ }^{15} \mathrm{~N}$ recovery was significantly greater in the $\mathrm{N}$-serve treatment group, presumably the result of less plant uptake and the persistence of ammonium in that treatment.

(3) Addition of $\mathrm{N}$-serve had no significant effect on soil immobilized ${ }^{15} \mathrm{~N}$ recovery for the soil-only groups. The high variability found in the group not containing $\mathrm{N}$-serve was most likely the result of poor initial treatment for 2 of the replicates where it was observed that about half of the ammonium solutions leaked to the soil surface during injections. This leakage would have promoted denitrification losses and is the most probable cause of the low overall recoveries for those 2 replicates.

(4) Apart from the 2 exceptional cases indicated in (3), overall ${ }^{15} \mathrm{~N}$ recoveries were high and no significant differences were found between any of the groups. The fairly constant mean \% loss (about $13 \%$ ) for all treatment groups implied that denitrification losses were very minor. Calculations using the data of Vlek and Stumpe (1978) revealed that, under these experimental conditions, ammonia volatilization could possibly account for $\mathrm{N}$ losses of 10 to $20 \%$.

\section{Experiment 2}

The dry weights of seedling components (leaves, stems, roots and total plant), along with total leaf area per plant after $158 \mathrm{~d}$ of growth in the ammonium or nitrate solutions, are shown in Fig. 1. For all components, a 2 -way analysis of variance showed a highly significant interaction ( $N$ source $X$ concentration) term which indicated different plant response to increasing ammonium and nitrate supply. Inspection of the group means ( $n=5$ replicates for each) in relation to the LSD $_{.05}$ values (Fig. 1) further shows that: 


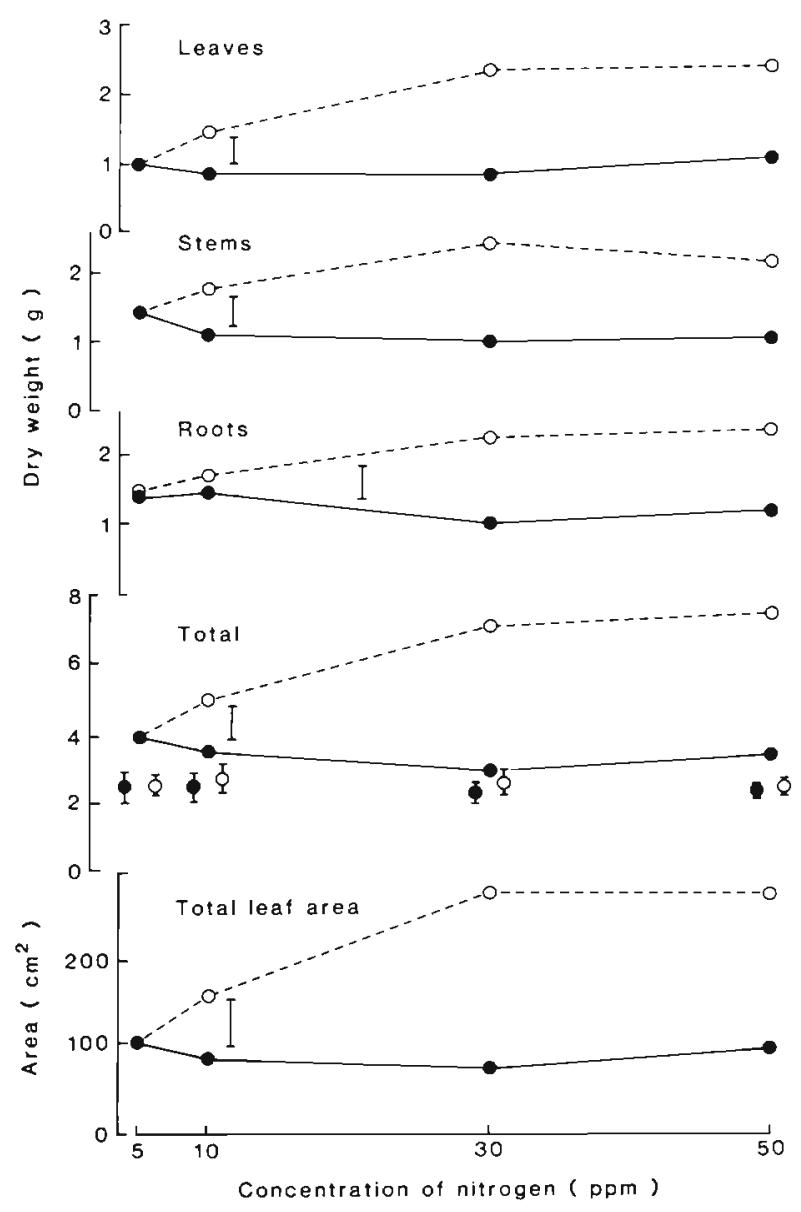

Fig. 1. Avicennia marina. Growth response of seedlings, by component, after growth in nutrient solution culture with either ammonium or nitrate as the nitrogen source - mean dry weights at harvest for leaves, stems, roots and total plant are shown. Total leaf area per plant at harvest (mean value, $\mathrm{n}=5$ ) is also shown. In all graphs: $-\mathrm{NH}_{4}^{+}$treatments; $\mathrm{ONO}_{3}^{-}$ treatments. Error bars: LSD os values calculated from analysis of variance. Graph for total growth also shows mean initial dry weights of seedlings used in experiments. Error bars here denote $95 \%$ confidence interval for mean initial dry weights

(1) There was no significant difference in growth between the different ammonium levels.

(2) Conversely, increased nitrate supply up to $30 \mathrm{ppm}$ $N$ resulted in significantly increased growth.

(3) Comparison of the final dry weights (whole plant) with initial values, also shown in Fig. 1, showed that growth was poor in all ammonium treatments.

The total nitrogen content of the plants (Table 2) mirrored the dry weight results. However, the $\mathrm{N}$ concentrations ( $\%$ by dry wt) of the plant components showed a different response (Table 3). At high levels of $N$ supply, stems and roots from ammonium treatments exhibited significantly higher $\mathrm{N}$ concentrations than those found for the nitrate treatments. This seemingly anomalous behaviour was most likely a result of dilu- tion in the much greater biomass resulting from the nitrate treatments.

Visual inspection of the plants at harvest also revealed striking differences between the plants supplied with ammonium or nitrate:

(1) All seedlings grown in nitrate media had developed multiple healthy growing point's ('branching') while all seedlings from ammonium treatments had only one active growth tip at the top of the plant. (2) All seedlings supplied with nitrate had developed an extensive fine root system whereas none of the seedlings supplied with ammonium had developed any fine roots (Fig. 2). Some of the latter seedlings had a small amount of fine roots, apparently dead (brown, non-turgid) which were probably remnants from the initial state of the seedlings.

\section{DISCUSSION}

The results from Experiment 1 strongly suggest that Avicennia marina seedlings grown in anaerobic soils exhibit substantially lowered nitrogen uptake rates when a nitrification inhibitor is added to the soil. It is possible that the lower uptake observed in this case was an artifact caused by a direct $N$-serve toxicity effect on the plants. However, only isolated cases of $\mathrm{N}$ serve toxicity to plants have been reported (Maftoun et al., 1982) and in such instances the symptoms were quite dramatic, for example, leaf curling and tendril stem growth. No such symptoms were observed in our

Table 3. Avicennia marina. Mean values ( $\mathrm{n}=5$ replicates for each) of nitrogen concentration ( $\%$ by dry weight) by component for seedlings from Experiment 2. Mean values for whole plant total $\mathrm{N}$ content $(\Sigma N)$ are also shown

\begin{tabular}{|c|c|c|c|c|}
\hline \multirow[b]{2}{*}{ Treatment } & \multicolumn{4}{|c|}{$\begin{aligned} \Sigma N= & \Sigma(N \% \times \text { dry wt }), \text { summed } \\
& \text { over all components }\end{aligned}$} \\
\hline & $\begin{array}{l}\text { Leaf } \\
N \%\end{array}$ & $\begin{array}{l}\text { Stem } \\
\mathrm{N} \%\end{array}$ & $\begin{array}{l}\text { Root } \\
N \%\end{array}$ & $\begin{array}{c}\Sigma \mathrm{N} \\
(\mathrm{mg})\end{array}$ \\
\hline 5 ppm $\mathrm{NH}_{4}^{+}-\mathrm{N}$ & $2.38 a^{\circ}$ & $0.76 \mathrm{a}$ & $1.32 \mathrm{a}$ & $51.4 \mathrm{a}$ \\
\hline $10 \mathrm{ppm} \mathrm{NH}+\mathrm{N}$ & $2.57 \mathrm{a}$ & $0.83 \mathrm{a}$ & $1.49 \mathrm{a}$ & $52.3 a$ \\
\hline $30 \mathrm{ppm} \mathrm{NH}{ }_{4}^{+}-\mathrm{H}$ & $3.22 \mathrm{~b}$ & $1.23 \mathrm{~b}$ & $2.00 \mathrm{~b}$ & $59.6 \mathrm{a}$ \\
\hline $50 \mathrm{ppm} \mathrm{NH} \mathrm{NH}_{4}^{+}-\mathrm{H}$ & $3.20 \mathrm{~b}$ & $1.21 \mathrm{~b}$ & $1.89 \mathrm{~b}$ & $71.5 \mathrm{a}$ \\
\hline $5 \mathrm{ppm} \mathrm{NO}_{3}^{-}-\mathrm{N}$ & $2.29 \mathrm{a}$ & $0.80 \mathrm{a}$ & $0.98 \mathrm{a}$ & $47.2 \mathrm{a}$ \\
\hline $10 \mathrm{ppm} \mathrm{NO}_{3}^{-}-\mathrm{N}$ & $2.72 \mathrm{a}$ & $0.74 \mathrm{a}$ & $1.23 \mathrm{a}$ & $73.0 \mathrm{a}, \mathrm{b}$ \\
\hline $30 \mathrm{ppm} \mathrm{NO}_{3}^{-}-\mathrm{N}$ & $2.99 \mathrm{~b}$ & $0.92 \mathrm{a}$ & $1.36 \mathrm{a}$ & $122.5 \mathrm{~b}$ \\
\hline $50 \mathrm{ppm} \mathrm{NO}_{3}^{-}-\mathrm{N}$ & $3.25 \mathrm{~b}$ & $0.84 \mathrm{a}$ & $1.10 \mathrm{a}$ & $127.6 \mathrm{~b}$ \\
\hline $\mathrm{LSD}_{05}$ & 0.59 & 0.25 & 0.48 & 22.0 \\
\hline \multicolumn{5}{|c|}{$\begin{array}{l}\text { Values, within a column, followed by a different letter } \\
\text { are significantly different from each other at the } p<0.05 \\
\text { level }\end{array}$} \\
\hline
\end{tabular}


experiments. Further, the addition of $\mathrm{N}$-serve to all treatments in Experiment 2 did not appear to inhibit growth in the seedlings supplied with nitrate. We therefore consider that the results of both experiments can be attributed to deprivation of nitrate rather than $\mathrm{N}$-serve toxicity.

The similar amounts of soil immobilized ${ }^{15} \mathrm{~N}$ recovery in the 'soil-only' and 'plant-soil + $\mathrm{N}$ serve' treatments of Experiment 1 also suggest that $N$-serve had no significant effect on the soil microbiota other than nitrifying bacteria. This agrees with Billen's (1976) conclusion that $\mathrm{N}$-serve is a highly specific inhibitor of nitrifying bacteria. Also, the essentially constant overall ${ }^{15} \mathrm{~N}$ recoveries in all treatments indicates that denitrification losses resulting from below-ground placement of ammonium, at low concentrations, are minimal. This conclusion was also reached by DeLaune et al. (1983) in their study of a Louisiana salt marsh system. This further implies that negligible nitrification occurred at the soil-water-air interface. Hence, the marked lowering of plant $N$ uptake in the presence of the nitrification inhibitor points to a substantial degree of nitrifying activity in the oxidized zones around the roots. This conclusion, however, is based on very indirect evidence and requires further experiments to demonstrate its validity

In any case, the results of Experiments 1 and 2 strongly suggest that deprivation of nitrate availability had an adverse effect on nitrogen uptake rate, growth and root development in Avicennia marina. Further, in the absence of nitrate, increasing the ammonium supply from 5 to $50 \mathrm{ppm} \mathrm{N}$ did not alleviate these effects.

These findings contradict the generally accepted view that nitrate is a very minor source of nitrogen for plants growing in anaerobic soils. Mendelssohn (1979), for example, reported mean annual nitrate reductase
Fig. 2. Avicennia marina. Roots of seedlings at harvest in Experiment 2:

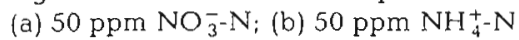
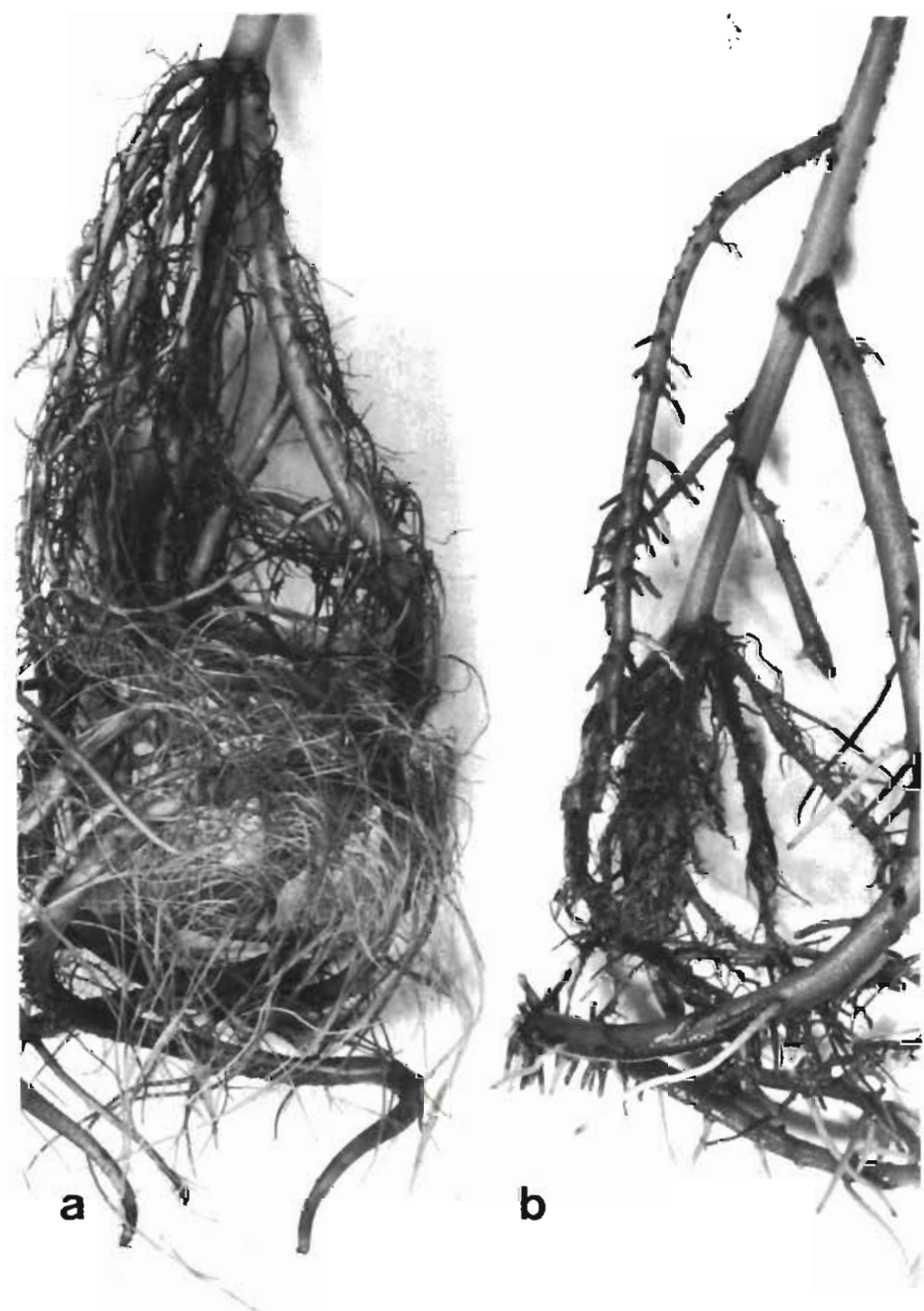
activities (NRA) of 0.1 and $0.06 \mu \mathrm{mol} \mathrm{NO} \mathrm{Ng}^{-1}$ (fresh wt) $\mathrm{h}^{-1}$ for leaves and roots in a Spartina alterniflora marsh. While these values appear low, it is interesting to calculate annual rates of $\mathrm{N}$ incorporation from the NRA values and to compare this estimate with other estimates of total plant $N$ incorporation for a typical $S$. alterniflora marsh. A reasonable estimate for the latter can be obtained from DeLaune et al. (1983); their estimate of plant $\mathrm{N}$ incorporation in a Louisiana marsh is $12 \mathrm{~g} \mathrm{~N} \mathrm{~m}^{-2} \mathrm{yr}^{-1}$ (above ground plant material only). Assuming that leaf and live root biomass in a typical marsh are about 250 and $1,000 \mathrm{~g}$ (fresh $w \mathrm{t}$ ) $\mathrm{m}^{-2}$ respectively (e.g. Turner, 1976 and references therein) and using the NRA values quoted above, an estimate of nitrate- $N$ incorporation can be calculated to be about $10 \mathrm{~g} \mathrm{~N} \mathrm{~m}^{-2} \mathrm{yr}^{-1}$. Although this estimate is approximate, it serves to suggest that nitrate utilization by $S$. alterniflora could account for a significant proportion of its $\mathrm{N}$ uptake requirements. While similar data do not appear to have been reported for mangroves, Iizumi (unpubl., this laboratory) has measured NRA values in mangrove leaf samples to be in the order of $0.1 \mu \mathrm{mol}$ $\mathrm{NO}_{2}^{-} \mathrm{g}$ (fresh $\left.\mathrm{wt}\right)^{-1} \mathrm{~h}^{-1}$, very similar to the values quoted for $S$. alterniflora.

Even if the above estimates are seriously in error, it appears that Avicennia marina seedlings require some degree of nitrate availability for optimal growth and particularly for root development. Differences between plant types may negate broad generalizations of a similar nitrate requirement in other species. We consider, however, that this topic deserves further attention in view of the apparently widespread nitrogen limitation of marsh and mangrove systems.

Acknowledgements. We acknowledge the expert technical assistance provided by A. L. Cogle and W. Peacock ( $N$ and ${ }^{15} \mathrm{~N}$ analyses), J. Wellington (assistance with laboratory experiments) and $\mathrm{M}$. Thyssen (graphical presentation). We also gratefully acknowledge critical reviews of the manuscript and editorial assistance provided by T. J. Smith and A. Dartnall.

\section{LITERATURE CITED}

Armstrong, W. (1971). Radial oxygen losses from intact rice roots as affected by distance from the apex, respiration and waterlogging. Physiol. Plant. 25: 192-197

Armstrong, $W$ (1978). Root aeration in the wetland condition In: Hook, D. E., Crawford, R. M. M. (ed, Plant life in anaerobic environments. Ann Arbor Science, Ann Arbor, Michigan, USA, p. 269-298

Billen, G. (1976). Evaluation of nitrifying activity in sediments by dark ${ }^{14} \mathrm{C}$-bicarbonate incorporation. Wat. Res. 10 : $51-57$

Boto, K. G., Wellington, J. T (1983). Phosphorus and nitrogen nutritional status of a northern Australian mangrove forest. Mar Ecol. Prog. Ser. 11: 63-69
Boto, K. G., Wellington, J. T. (1984). Soil characteristics and nutrient status in a northern Australian mangrove forest. Estuaries 7: 61-69

Bremmer, J. M. (1965). Total nitrogen. In: Black, C. A. (ed.) Methods of soil analysis. Agron. 9. American Society of Agronomy, Madison, Wisconsin, USA, p. 1149-1178

Bremmer, J. M., Keeney, D. R. (1966). Determination and isotope ratio analysis of different forms of nitrogen in soils. 3: Exchangeable ammonium, nitrate and nitrite by extraction - distillation methods. Soil Sci. Soc. Am. Proc. 30 $577-582$

Buresh, R. J., DeLaune, R. D., Patrick, W. H., Jr. (1980). Nitrogen and phosphorus distribution and utilization by Spartina alterniflora in a Louisiana Gulf coast marsh. Estuaries 3: 111-121

DeLaune, R. D., Smith, C. J., Patrick, W. H., Jr. (1983). Nitrogen losses from a Louisiana gulf coast marsh. Estuar. coast. Shelf Sci. 17: 133-141

Gallagher, J. L. (1975). Effect of an ammonium nitrate pulse on the growth and elemental composition of natural stands of Spartina alterniflora and Juncus roemerianus. Am. J. Bot. 62: 644-648

Gleason, M. L., Zieman, J. C. (1981). Influence of tidal inundation on internal oxygen supply of Spartina alterniflora and Spartina patens. Estuar. coast. Shelf Sci. 13: 47-57

Howes, B. L., Howarth, R. W., Teal, J. M., Valiela, I. (1981). Oxidation-reduction potentials in a salt marsh: spatial patterns and interactions with primary production. Lim. nol. Oceanogr. 26: 350-360

Maftoun, M., Sameni, A. M., Darbeheshti, M., Yasrebi, J. Hojjati, S. M. (1982). Toxicity of nitrapyrin to sunflower under different $N$ nutrition regimes. Plant Soil 65: 411-414

Mendelssohn, I. A. (1979). Nitrogen metabolism in the height forms of Spartina alterniflora in North Carolina. Ecology 60: $574-584$

Mendelssohn, I. A., Postek, M. T. (1982). Elemental analysis of deposits on the roots of Spartina alterniflora Loisel. Am. J. Bot. 69: 904-912

Morris, J. T (1980). The nitrogen uptake kinetics of Spartina alterniflora in culture. Ecology 61: 1114-1121

Onuf, C. P., Teal, J. M., Valiela, I. (1977). Interaction of nutrients, plant growth and herbivory in a mangrove ecosystem. Ecology 58: 514-526

Ross, P. J., Martin. A. E. (1970). A rapid procedure for preparing gas samples for nitrogen-15 determination. Analyst (Lond.) 95: 817-822

Saenger, P. (1982). Morphological, anatomical and reproductive adaptations of Australian mangroves. In: Clough, B. F. (ed.) Mangrove ecosystems in Australia. Aust. Inst. Mar. Sci. Aust. Nat. Univ. Press, Canberra, Australia, p. $153-191$

Saffigna, P. G., Waring, S. A. (1977). Prevention of ${ }^{15} \mathrm{~N}$ cross contamination during distillation and potentiometric titration of ${ }^{15} \mathrm{~N}$-labelled samples. Analytica chim. Acta 89: 203-207

Sahrawat, K. L., Mukerjee, S. K. (1977). Nitrification inhibitors. I. Studies with Karanjin, a furanoflavonoid from Karanja (Pongamia glabra) seeds. Plant Soil 47: 27-36

Scholander, P. F., Scholander, S. 1. (1955). Gas exchange in the roots of mangroves. Am. J. Bot. 42: 92-98

Sokal, R. R., Rohlf, F. J. (1981). Biometry. W. H. Freeman and Co., San Francisco

Teal, J. M., Kanwisher, J. W. (1966). Gas transport in the marsh grass, Spartina alterniflora. J. exp. Bot. 17: 355-361

Teal, J. M., Valiela, I., Berlo, D. (1979). Nitrogen fixation by rhizosphere and free-living bacteria in salt marsh sediments. Limnol. Oceanogr. 24: 126-132 
Turner, R. E. (1976). Geographic variations in salt marsh macrophyte production: a review. Contr. mar Sci. 20: $47-68$

Valiela, I., Teal, J. M. (1974). Nutrient limitation in salt marsh vegetation. In: Reimold, R. J., Queen, W. H. (ed.) Ecology of halophytes. Academic Press, New York, p. 547-563
Vlek, P. L. G., Stumpe, J. M. (1978). Effects of solution chemistry and environmental conditions on ammonia volatilization from aqueous systems. Soil. Sci. Soc. Am. Proc. 42 $416-421$

This paper was submitted to the editor; it was accepted for printing on October 7,1984 